\title{
WASHING TEST OF KENDILO COAL USING A SINK-FLOAT METHOD TO IMPROVE ITS QUALITY
}

\author{
STUDI PENCUCIAN BATUBARA KENDILO MENGGUNAKAN UJI \\ ENDAP-APUNG UNTUK MENINGKATKAN KUALITASNYA
}

\author{
WANDA ADINUGRAHA ${ }^{1,3}$, NANA SULAKSANA ${ }^{3}$, HENDARMAWAN ${ }^{3}$, \\ BINARKO SANTOSO ${ }^{2}$, DATIN F. UMAR ${ }^{2}$, and FITRI AMALIA ${ }^{4}$ \\ ${ }^{1}$ Centre for Human Resources Development Geology, Mineral, and Coal \\ Jl. Jenderal Sudirman 623 Bandung 40211 \\ Ph. (022) 6076756, Fax. (022) 6035506 \\ e-mail: wanda.adinugraha@esdm.go.id \\ ${ }^{2} \mathrm{R} \& \mathrm{D}$ Centre for Mineral and Coal Technology \\ Jalan Jenderal Sudirman 623 Bandung 40211 \\ ${ }^{3}$ Faculty of Geological Engineering, Padjadjaran University \\ Jl. Raya Bandung Sumedang KM 21, Jatinangor 45363 \\ ${ }^{4}$ Mining Engineering, Faculty of Earth and Energy Technology, Trisakti University \\ Jl. Kyai Tapa No. 1, Jakarta
}

\begin{abstract}
Kendilo coal is known as a high-ash content type. Beneficiating such the coal for gasification process needs to wash the coal first. The purpose of washing is to lower the ash content until the permitted amount of about $10 \%$. Samples for coal washing were obtained from PT. Kendilo Coal Indonesia at Pasir Belengkong, Paser Regency, East Kalimantan. The samples were taken at Bindu and Betitit Block, which containing ash of about $20 \%-30 \%$. To wash the coal samples, a sink-float method was applied to test its separation characteristic. The washing process employed three sizes fraction, i.e, $12.5+5.6,-5.6+1.18$, and $-1.18 \mathrm{~mm}$ and the separation density was varied between 1.3 to $1.6 \mathrm{~g} / \mathrm{cc}$ within the interval of 0.1 . The liquid solutions as the separation media were made from mixing of perchloroethylene and toluene. From the coal washability curve, the best coal washing in order containing ash content of about $8 \%$ in the case of Bindu Block's coal, occurs at the fraction of $12.5+5.6 \mathrm{~mm}$, at density separator of $1.36 \mathrm{~g} / \mathrm{cc}$ with the recovery of $50 \%$. While the coal of Betitit's Block, the washed coal was $50.82 \%$ at similar fraction but at different density separator of $1.39 \mathrm{~g} / \mathrm{cc}$
\end{abstract}

Keywords: coal washability, sink and float test, recovery, coal washability curve

\begin{abstract}
ABSTRAK
Batubara Kendilo termasuk ke dalam jenis batubara dengan kadar abu yang tinggi. Pengolahan batubara tersebut sebelum digunakan sebagai umpan proses gasifikasi perlu dilakukan dengan cara mencucinya terlebih dahulu. Tujuan pencucian adalah untuk menurunkan kadar abu sehingga sesuai dengan kadar abu yang dipersyaratkan, yaitu $<10 \%$. Pengujian ini menggunakan percontoh batubara yang diambil dari PT. Kendilo Coal Indonesia, Kecamatan Pasir Belengkong, Kabupaten Paser, Provinsi Kalimantan Timur. Percontoh batubara tersebut diambil dari Blok Bindu dan Betitit yang memiliki kadar abu tinggi sekitar $20 \%$ - 30\%. Pencucian batubara dilakukan dengan cara uji endap-apung untuk mengetahui karakteristik pemisahan. Proses pencucian dilakukan terhadap tiga fraksi ukuran, yaitu -12,5+5,6; -5,6+1,18; dan -1,18 mm dengan densitas pemisah mulai dari 1,3 sampai $1,6 \mathrm{~g} / \mathrm{ml}$ dengan interval 0,1 . Media pemisah pada densitas tertentu, dibuat dengan cara mencampurkan dua jenis larutan yaitu perchloroethylene dan toluena. Dari kurva ketercucian batubara, jika kadar abu batubara yang diinginkan $8 \%$, untuk batubara Blok Bindu kondisi proses pencucian yang terbaik terjadi pada fraksi ukuran -12,5+5,6 mm pada densitas pemisah 1,36 g/ml dengan perolehan batubara bersih terbesar, yaitu 50\%. Begitu juga dengan batubara Blok Betitit, perolehan batubara bersih tertinggi sebesar $50,82 \%$ terjadi pada fraksi ukuran yang sama namun media pemisah berdensitas $1,39 \mathrm{~g} / \mathrm{ml}$.
\end{abstract}

Kata kunci: pencucian batubara, uji endap-apung, perolehan, kurva ketercucian 


\section{INTRODUCTION}

Coal is a sedimentary deposit that contains the organic and inorganic components. The organic components are represented by the macerals, while the inorganic ones belong to the minerals. The proportions of both components will affect the coal quality, mainly its ash and sulfur contents as well as its calorific value (Anggayana and Widayat, 2007). Coalification occurs due to the high pressure and temperature within the earth that persists in the very long time while its characteristics are caused by the difference of the coal precursor (the type of the ancient plant), depositional environment, condition and degree of change in type, as well as quantity and impurity distribution.

Indonesian coal is distributed from Sumatra through Papua, noted by several big basins at Aceh, South Sumatra, East Kalimantan, and South Kalimantan. Based on the Geological Agency of Indonesia data, the total Indonesian coal resource attained161 billion tons, performing the coal reserve around 28 billion tons. Of such a figure, the Indonesian coal reserve is only $0.6 \%$ of the world coal reserves (Arif, 2014).

Geological condition and several parameters related to the seam characteristics are the factors that should be considered to mine the coal deposits. The relatively cheap of the coal price in the costs of coal mining, processing, and transporting to the market serves as an important factor in the economy of the project and should be balanced by the quality of the mined coal (Holuszko, 1994).

Coal quality varies vertically due to an increase in ash content at the bottom of the coal seam and increased sulfur at the top of the coal seam. Meanwhile, horizontally coal quality also have a variety predominantly due to the maturity process of the coal during its genesis such as pressure from sedimentation process and due to the heat from magmatic activity (Sudarsono, 2003).

One of coal quality improvements consists of eliminating the high ash content through a washing process by utilizing the relative density variation of the materials within the coal. The clean coal is separated from its high ash-content impurities and its middling.
The relationship between the relative density and the ash content brings about the control of relative density in the coal washing that will keep maintaining the clean coal with a certain ash content. As a result, the calorific value, sulfur content and other coal characteristics can be determined (Osborne, 1988; Thomas, 2012).

When washing the coal, the washability characteristics are the important factors in the economic evaluation of the coal seam as well as in verifying the coal quantity and quality that can be obtained from a certain coal seam. Such the data can also be utilized for evaluating the performance of coal washing equipment. The relative density distribution of the will-be-washed dirty coal should be identified prior to washing it. It means that it should be known the proportion of coal with low, intermediate, and high relative densities, as well as its ash contents. If the above-required data are available, the coal washing system can easily be determined and the clean and middling coals, as well as its impurities and the ash content, can be predicted.

The high ash content of the coal occurs due to a lot of mineral matter within the coal that will yield the coal ash residue when burnt. The coal mineral matter normally associates with the macerals - the organic contents within the coal that come from the remains of the plant- and other organism fossils. The existence of mineral aggregates in the coal seam such as dispersed grains, nodules, lenticles, and bands can be detected both macroscopically and microscopically. Some of the fine minerals are found within the coal performing the diameter of no bigger than a few microns (more or less 65 microns) and unite with the macerals (notably desmocollinite). Such a mineral can only be identified by an electron microscope. The minerals that are associated with the macerals will be hard to be eliminated (ASTM D 2798-91, 1994).

The coal was sampled at Bindu-Betitit Block of PT. Kendilo Coal Indonesia, about $15 \mathrm{~km}$ to the west of Tanah Grogot, Paser Regency, East Kalimantan (Figure1). It belongs to Kuaro Formation deposited within a Paser sub-basin - a part of Kutai Basin in East Kalimantan (Harahap et al., 2003; Santoso, 2011). 


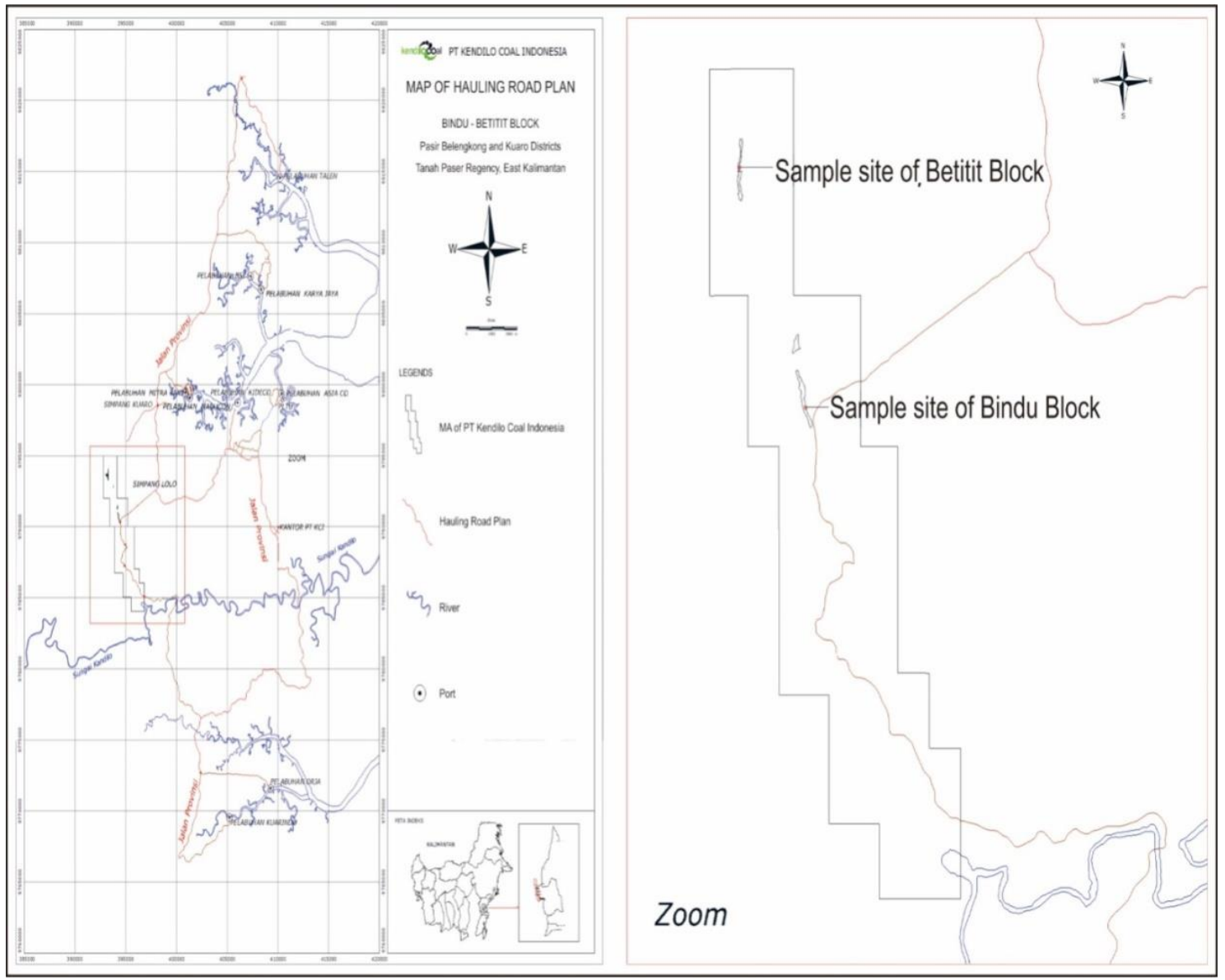

Figure 1. Map of the sampling site (PT. KCI, 2010).

As the study site, Bindu-Betitit Block shows a large number of coal resources that contain a high ash content (Figure 2). Currently, the coal that is known as the Kendilo coal belongs to PT Kendilo and has not been mined yet. Referring to its high ash content, it requires a method to evaluate the coal characteristics. The method was a washability test. The objective of the present study is to evaluate the washability characteristics of Kendilo coal through a float-sink test.

A previous washing test study was conducted on the Peranap Coal containing $5.56 \%$ ash. Using various fractions of size > $31.5 \mathrm{~mm}$; -31.5+5.6 mm; -5.6+2.36 mm; $2.36+0.6 \mathrm{~mm}$; and $<0.6 \mathrm{~mm}$, the results showed that the wash test with the separation density of 1.54 could decrease the ash content by $5 \%$, with the largest gain being $93.94 \%$ in the coal size fraction $<0.6$ mm (Umar, 2016).

Other coal washing tests had also been carried out on coal having an ash content of $7.91 \%, 5.73 \%$, and $6.76 \%$ within the size fractions of $-12.5+5 \mathrm{~mm} ;-5+1.68 \mathrm{~mm}$, and $1.68+0.85 \mathrm{~mm}$. The results showed that the yield of coal composite was obtained $67.11 \%$ and $73.6 \%$ with ash content was $3.57 \%$ and $4.04 \%$ using media densities of 1.3 and 1.4 respectively (Adinugraha, 2007).

In this study, the raw materials of coal were originated from Kendilo's coal seams that have a high ash content of about $20 \%$ $30 \%$. The tests results I provide a washability curve that would be analyzed to understand its washability characteristics base on particle size fractions and media densities that may affect the coal quality. 


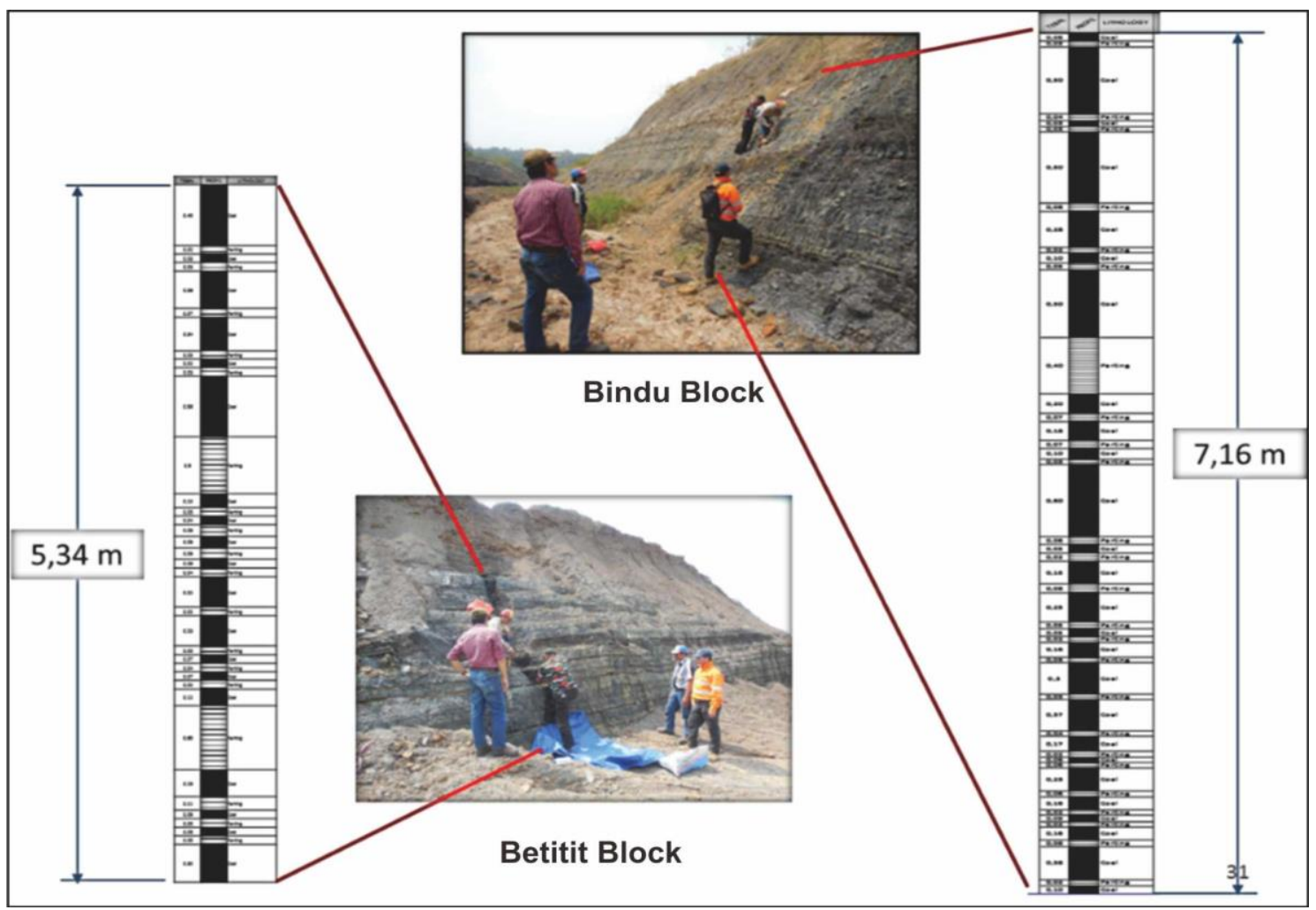

Figure 2.The coal seam at Bindu-Betitit Block.

\section{METHODS}

There are two actions that should be performed to conduct the coal washing. Those are size distribution and sink - float tests. The former was known as sieving analysis, namely separating the particles by their different sizes. The later or the sinkfloat test was conducted to all derived fractions.

Sample preparation for the sink-float study was started by reducing the particle size to the required size. The process included crushing, milling, and sieving. The final desired particles after sieving were those that have sizes of $-12.5+5.6,-5.6+1.18$, and -1.18 $\mathrm{mm}$. Each fraction was weighted to be used for sieving and characterization analyses including its coal quality.

Prior to conducting the sink-float test, the first step was preparing the separation solution. Mixing the perchloroethylene homogenously with the toluene resulted in a new solution that retained density of $1.3 \mathrm{~g} / \mathrm{cc}$ to $1.6 \mathrm{~g} / \mathrm{cc}$ that will be used as media separator for the sink-float tests. The volume ratio of toluene and perchloroethylene to be mixed is denoted in Table 1, which was calculated base on the formula:

$$
\rho n \times V n=(\rho 1 \times V 1)+(\rho 2 \times V 2)
$$

where :

$\rho n=$ relative density of the separation solution

$\mathrm{Vn}=$ volume of the separation solution

$\rho 1=$ density of Toluene $(0.86 \mathrm{~g} / \mathrm{cc})$

$\mathrm{V} 1$ = volume of Toluene

$\rho 2=$ density of Perchlorethylene $(1.62 \mathrm{~g} / \mathrm{cc})$

$\mathrm{V} 2$ = volume of Perchlorethylene

Table 1. Volume of toluene and perchloroethylene to be mixed

\begin{tabular}{ccc}
\hline $\begin{array}{c}\text { Density of the } \\
\text { separation } \\
\text { solution }(\mathrm{g} / \mathrm{cc})\end{array}$ & $\begin{array}{c}\text { Volume of } \\
\text { Toluene } \\
(\mathrm{cc})\end{array}$ & $\begin{array}{c}\text { Volume of } \\
\text { Perchlorethylene } \\
(\mathrm{cc})\end{array}$ \\
\hline 1.3 & 421.05 & 578.95 \\
1.4 & 289.47 & 710.53 \\
1.5 & 157.89 & 842.11 \\
1.6 & 26.32 & 973.68 \\
\hline
\end{tabular}

Hydrometer was applied to measure the real density. To get a higher liquid density than $1.3 \mathrm{~g} / \mathrm{cc}$, more perchloroethylene should be 
added instead of toluene, while a lower density was obtained by adding more toluene instead of perchloroethylene.

The sink-float test was performed by dipping the sample into a media separator of a certain density and stirred in one minute in a breaker glass. The initial media for the test was the media that had the smallest density $(1.3 \mathrm{~g} / \mathrm{cc})$. Let the process taken place for 10 minutes until the sink and float particles emerged. Both sink and float materials were then separated, dried and weighed. The floating materials were then analyzed for its ash content, while the sink materials were re-dipped into the solution retaining higher density than that of the previous one. The similar process was then applied to all fractions. and the results were shown in Tables 2 and 3. Analyzing and interpreting data from both tables depicted several washability curves.

\section{RESULTS AND DISCUSSION}

Coal gasification requires coal material that has low ash content $(<10 \%)$, therefore, the desirable ash content after washing should not be more than $8 \%$. Based on the sinkfloat tests, the yielded clean coal is found $50 \%$ for Bindu coal and $50.82 \%$ for Betitit coal. Both coals represent a $-12.5+5.6 \mathrm{~mm}$ fraction. The density of media separator for both types are 1.36 and $1.39 \mathrm{~g} / \mathrm{cc}$ respectively. Such the results are achieved by the washability curve as depicted in Figures 3 and 4, which are interpreted from Table 2 and 3.

Using the fraction of $-5.6+1.18 \mathrm{~mm}$ for the sink-float test of the coals from Bindu and Betitit's Blocks yielded the recovery of $46.41 \%$ and $35.57 \%$ respectively. The tests employed the media separator that retained it's density of $1.37 \mathrm{~g} / \mathrm{cc}$. The yields of the sink-float test for the coal fraction of 1.18 $\mathrm{mm}$ produced a recovery of $19.37 \%$ for the Bindu coal and $11 \%$ for the Betitit coal. Both used the media separator of 1.37 and 1.34 $\mathrm{g} / \mathrm{cc}$, respectively. Table 4 represents the results of coal washing that achieved $8 \%$ ash content.

The study shows that there is a tendency regarding the recovery of the clean coal; the finer the coal fraction the smaller the yielded clean coal. Depending on the size of coal particles or the severity of the reduction process due to crushing or grinding, a part of the mineral matter will be impossible to separate from coal. From a practical point of view, the terms "extraneous" and "inherent" mineral matter are usually used to distinguish between ash-forming mineral matter which is separable by physical methods, and that which is not. Extraneous mineral matter invariably refers to epigenetic minerals, whereas the term "inherent" may be applied to syngenetic or epiclastic minerals. What the so-called "inherent" mineral matter actually represents is questionable. It does reflect, however, the amount of mineral matter intergrown with the coal in a particular size fraction. Recent research shows that even mineral matter as fine as 1 micron in size can be separated if liberated by fine crushing and grinding. In this context, inherent mineral matter represents only inorganic elements which are confined to the coal molecular structure and which can only be removed by chemical treatment. (Holuszko, 1994). When conducting the size reduction, the inorganic particles are supposed to be separated from the coals and will sink when immersed into a media separator (Sudarsono, 2003).

Due to the existence of inorganic particles within the coals, it is quite important to conduct the coal washing process. Coal characteristic test shows that quartz $\left(\mathrm{SiO}_{2}\right)$ and hematite $\left(\mathrm{Fe}_{2} \mathrm{O}_{3}\right)$ are two dominant inorganic minerals within the samples. The hematite occurs as a nodule and syngenetically developed at the early coalification. The material is microscopically dispersed and associated with the macerals. The easiest to separate are the epigenetic minerals, while epiclastic and syngenetic minerals are more difficult to remove by physical separation (Cook, 1981; Falcon and Falcon, 1983). Epigenetic minerals are easily liberated when the size is reduced to increase the yield of clean coal. Epiclastic and syngenetic minerals (clays, quartz, pyrite, siderite) are not usually liberated during the coarse coal crushing. Referring to this fact, separating the inorganic minerals from the coals will be difficult if only uses the sink-float test. The coal samples from BinduBetitit Blocks are supposed to contain a lot of inorganic particles that affect the results of coal washability. 


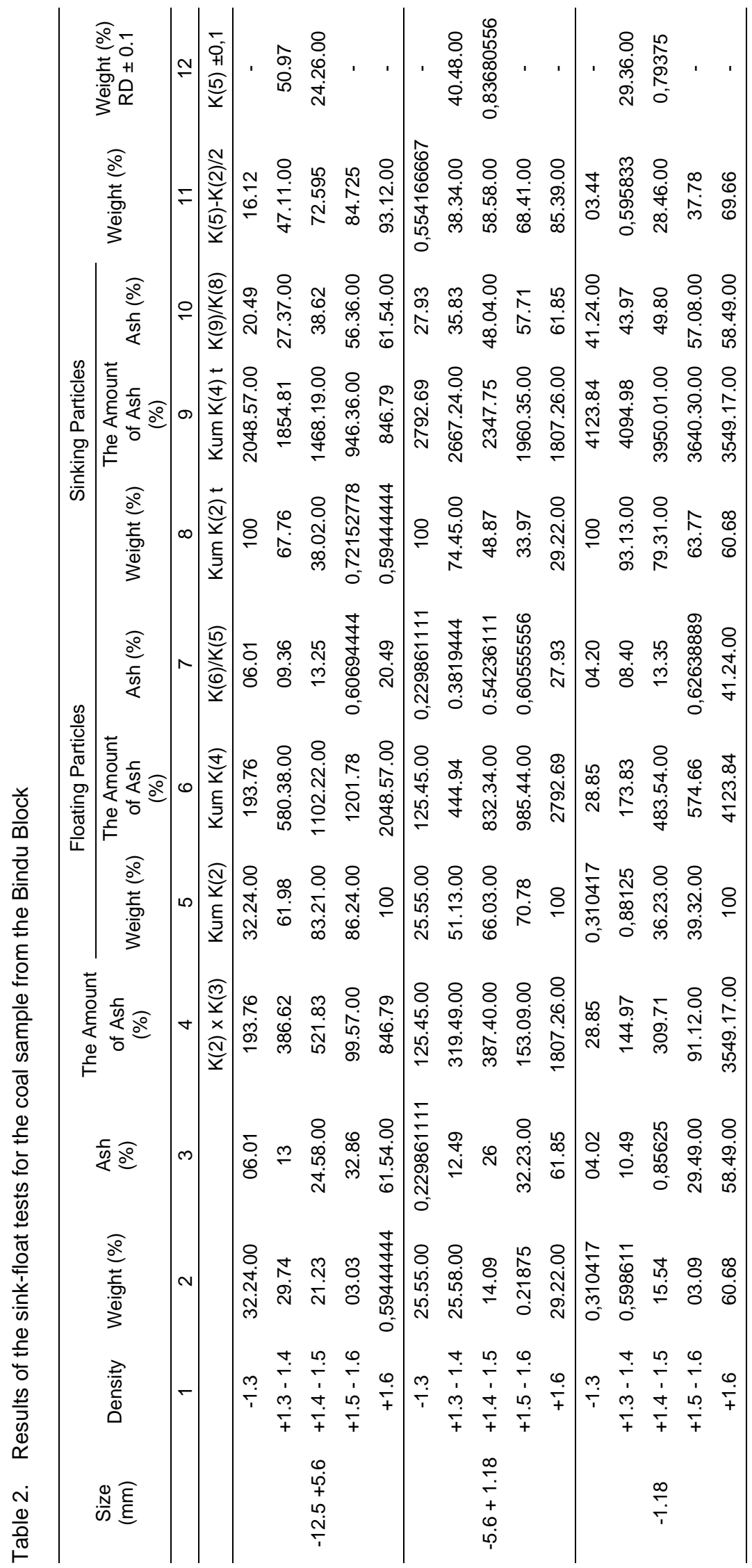




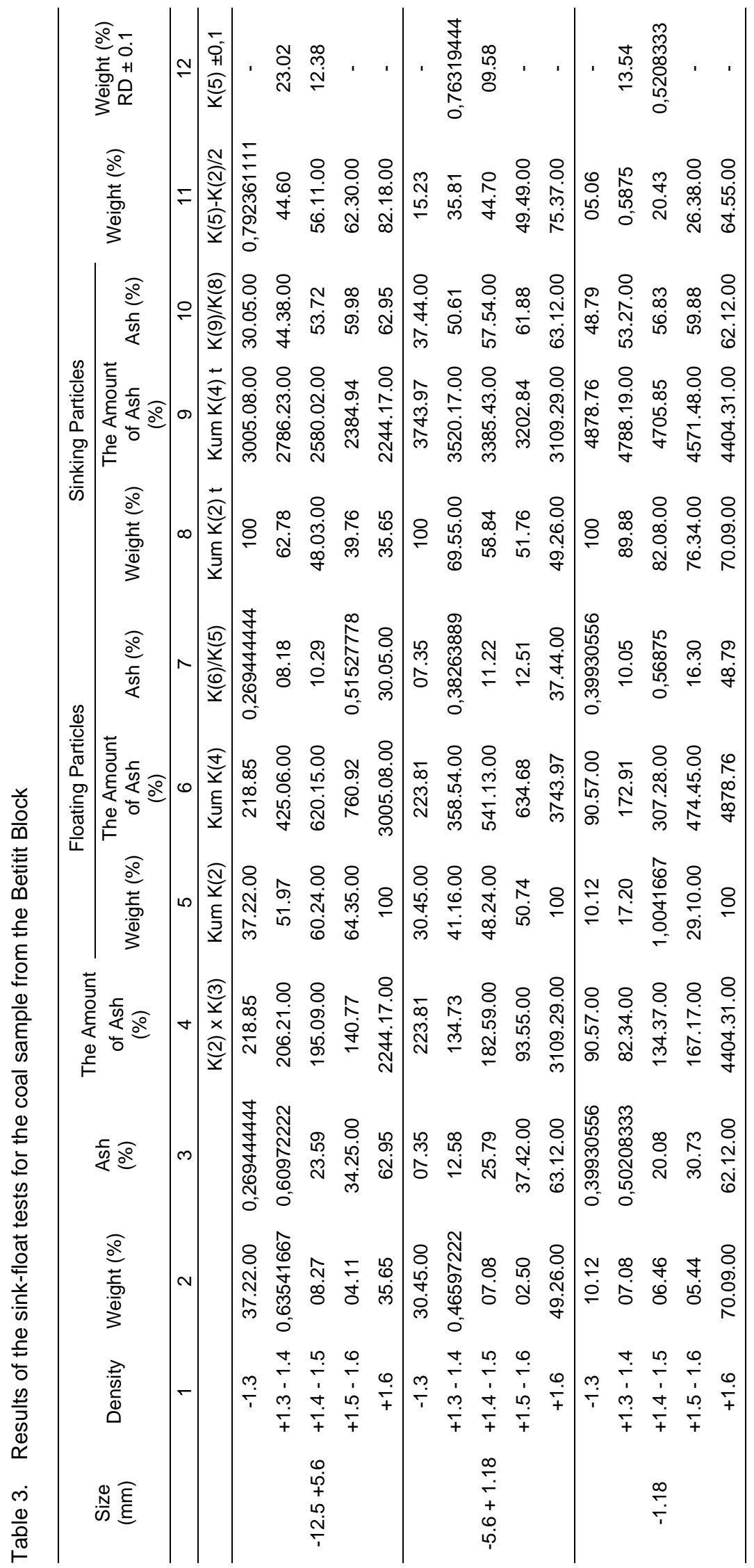




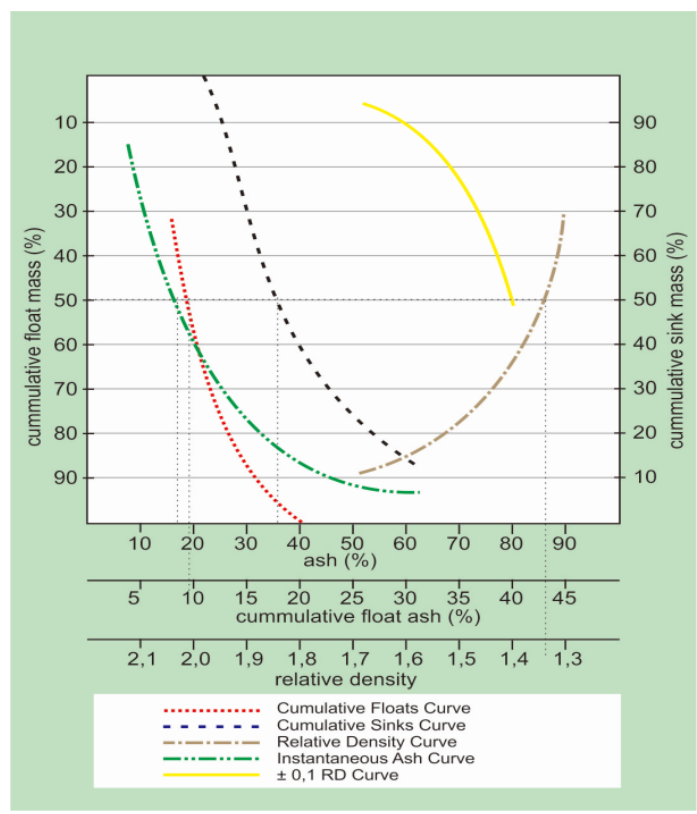

(a)

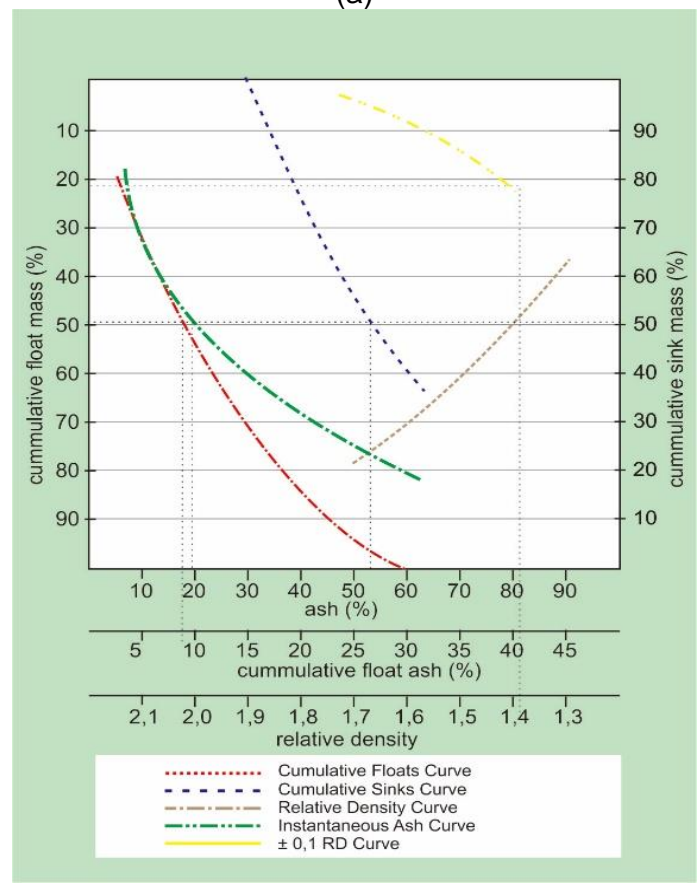

(c)

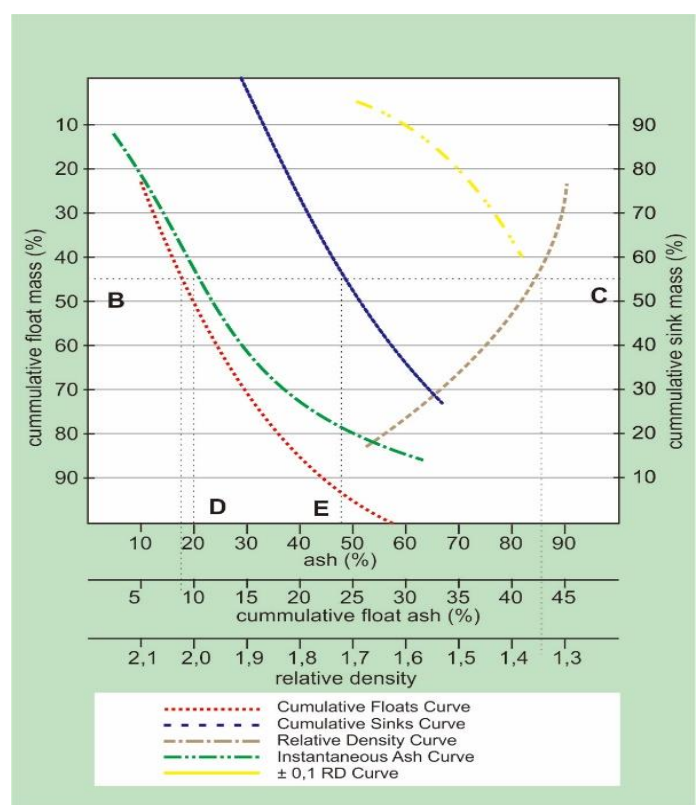

(b)

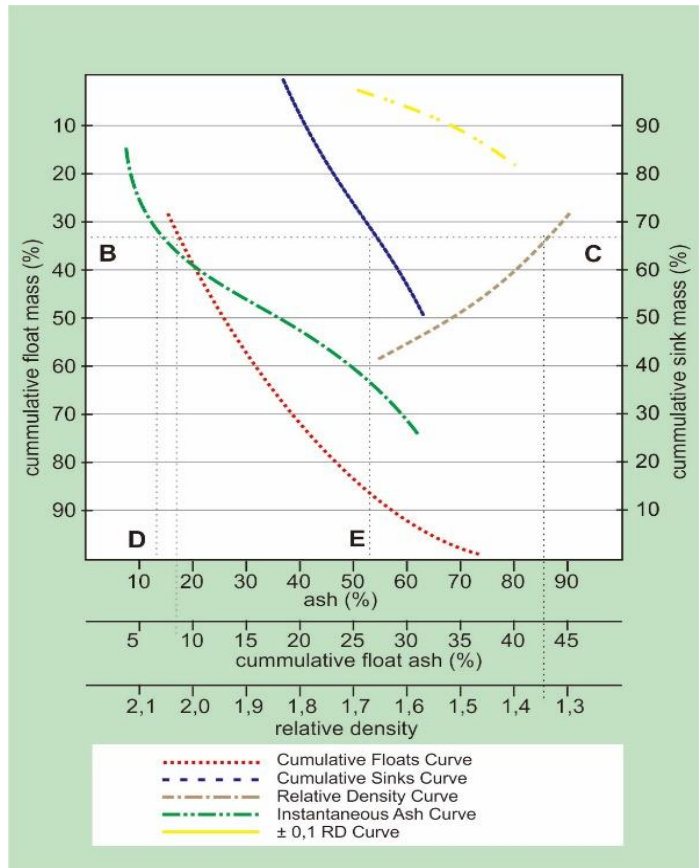

(d)

Figure 3. Washability curve for Bindu Block coal ( $a$ and b) and Betitit Block coal ( $c$ and d). The used fractions for either Bindu Block coal or Betitit Block Coal are $-12.5+5.6$ and $-5.6+1.18 \mathrm{~mm}$. 


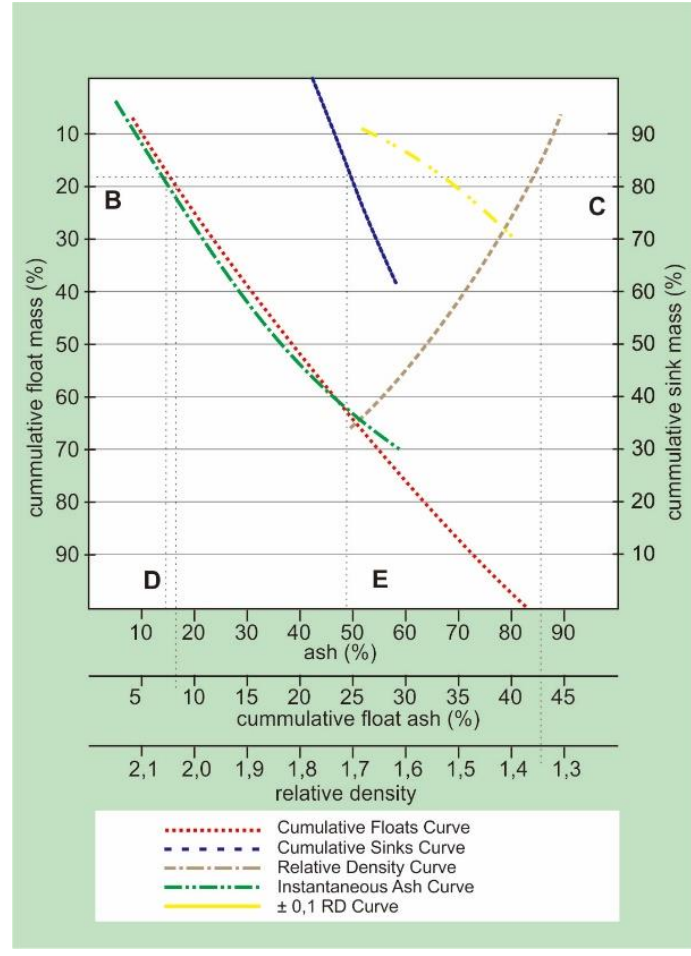

(a)

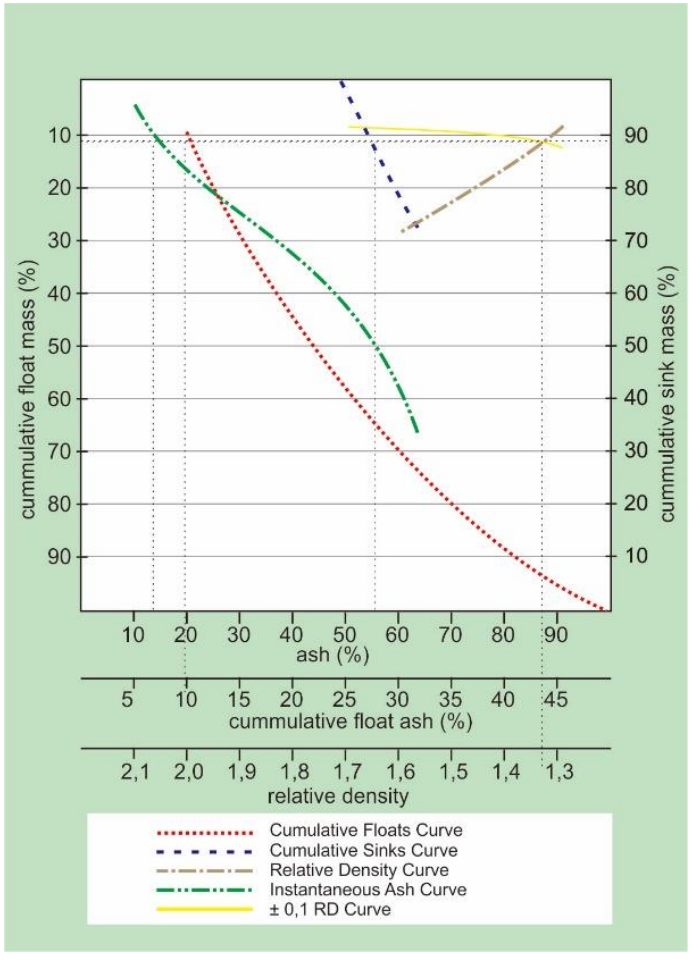

(b)

Figure 4. Washability curve for Bindu Block coal (a) and Betitit Block coal (b). The used fraction for either Bindu Block coal or Betitit Block Coal is $-1.18 \mathrm{~mm}$.

Table 4. Results of coal washing to obtain the $8 \%$-ash content

\begin{tabular}{lccccccc}
\hline \multirow{2}{*}{ Sample Code } & Fraction & $\begin{array}{c}\text { Ash } \\
\text { Content } \\
(\%)\end{array}$ & $\begin{array}{c}\text { Recovery } \\
(\%)\end{array}$ & $\begin{array}{c}\text { Ash } \\
\text { Content } \\
(\%)\end{array}$ & $\begin{array}{c}\text { Recovery } \\
(\%)\end{array}$ & $\begin{array}{c}\text { Relative } \\
\text { Density }\end{array}$ & $\begin{array}{c}\text { True Ash } \\
\text { Content } \\
(\%)\end{array}$ \\
\hline \multirow{3}{*}{ Bindu } & $-12.5+5.6$ & 8 & 50 & 34.83 & 50 & 1.36 & 15.25 \\
& $-5.6+1.18$ & 8 & 46.41 & 44.56 & 53.59 & 1.37 & 18.90 \\
& -1.18 & 8 & 19.37 & 50 & 80.63 & 1.37 & 14.08 \\
\hline \multirow{3}{*}{ Betitit } & $-12.5+5.6$ & 8 & 50.82 & 53 & 49.18 & 1.39 & 19.17 \\
& $-5.6+1.18$ & 8 & 35.57 & 54.23 & 64.43 & 1.36 & 12.52 \\
\hline
\end{tabular}

It is suggested to lengthen the time of separation process to get the best results. By extending the time, it is expected that the clean coal is completely separated from the dirty one. However, the separation time should be adjusted to the permeability of coal to be washed and the number of used media separator as such a media is volatile.

To obtain a maximum result, it is also suggested to enhance the number of size fraction and the range of relative separation density. This will help to get the detail data when making a better washability curve. A further study regarding coal petrography and geology also needs to be conducted to be more understood the effect of inorganic material existence during the sink-float tests.

\section{CONCLUSIONS}

The sink-float tests on the coal samples from Bindu-Betitit's Block show that the finer the particles size, the smaller the yielded clean coals. The highest fraction $(-12.5+5.6$ $\mathrm{mm}$ ) of either Bindu Block or Betitit Block provides recovery of $50 \%$ for Bindu Block 
and 50.82 for Betitit Block. Coal washing for the samples of Bindu-Betitit's Block is classified tough to be accomplished due to its particle size. The finer the size, the smaller the yielded clean coal.

Dispersed inorganic minerals associated with the macerals affect the result of coal washing. The inorganic minerals are hard to be separated if the separation process employs only the sink-float test. Due to the difficulty in the washing process that produce inconsiderable coal recovery of $8 \%$ ash content, the Kendilo coals from BinduBetitit Block is not feasible for gasification feed. However, the maximum yield from the sink-float test might be achieved up to $86.24 \%$ to decrease the ash content down to $13.94 \%$. So that Kendilo coal is very possible to be used as fuel of PLTU. In addition, the results of this study can also be inputted for PT. Kendilo Coal Indonesia if the economic feasibility evaluation had been done.

\section{ACKNOWLEDGEMENTS}

The authors would like to appreciate the Centre for Human Resources Development Geology, Mineral, and Coal for funding the research, as well as the Research and Development Centre for Mineral and Coal Technology for the permission to use laboratory facilities. Thanks also to PT. Kendilo Coal Indonesia for providing the coal samples.

\section{REFERENCES}

Adinugraha, W. (2007) "Pencucian batubara menggunakan chance cone dengan media hematite," Publikasi TMB, 1(2), pp. 8-15.

Anggayana, K. and Widayat, A. H. (2007) "Interpretasi fasies/lingkungan pengendapan batubara dan variasi sulfur untuk rekomendasi strategi eksplorasi. Kasus: Seam R, daerah Lati, sub-cekungan Berau, cekungan Tarakan," Jurnal Geoaplika, 2(1), pp. 35-52.

Arif, I. (2014) Batubara Indonesia. Gramedia Pustaka Utama.
ASTM D 2798-91 (1994) "Standard test method for microscopical determination of the reflectance of vitrinite in a polished specimen of coal," in Annual Book of ASTM Standards: Gaseous Fuels; Coal and Coke, sec. 5, v. 5.05. ASTM International, pp. 280-283.

Cook, A. C. (1981) "What Are We Trying to Separate?," Separation Science and Technology, 16(10), pp. 1545-1569. doi: 10.1080/01496398108058315.

Falcon, L. M. and Falcon, R. M. S. (1983) "The application of coal petrography to certain beneficiation techniques on South African coal," Geological Society of South Africa, 7(137-148).

Harahap, B. H., Bachri, S., Baharuddin, Suwarna, N., Panggabean, H. and Simandjuntak, T. O. (2003) Stratigraphic lexicon of Indonesia. Bandung: Geological Research and Development Centre.

Holuszko, M. E. (1994) "Washability characteristics of British Columbia coals." British Columbia Ministry of Energy, Mines and Petroleum Resources, pp. 1-36. Available at: http://www.empr.gov.bc.ca/Mining/Geos cience/PublicationsCatalogue/Papers/D ocuments/Paper1994-2.pdf.

Osborne, D. G. (1988) Coal preparation technology. Vol. 1. Graham \& Trotman.

PT. KCl (2010) Laporan eksplorasi PT. KCl, Indonesia.

Santoso, B. (2011) "Organic petrology of selected coal samples of eocene kuaro formation from Pasir Area-East Kalimantan," Indonesian Mining Journal, 14(3), pp. 146-153. Available at: http://jurnal.tekmira.esdm.go.id/index.ph p/imj/article/view/485.

Sudarsono, A. S. (2003) Pengantar preparasi dan pencucian batubara. Bandung: Institut Teknologi Bandung.

Thomas, L. (2012) Coal Geology. 2nd Ed. WileyBlackwell.

Umar, D. F. (2016) "Studi ketercucian batubara untuk proses gasifikasi dan pembakaran," in Prosiding Seminar Nasional Kimia Dalam Pembangunan. Yogyakarta: Jaringan Kerjasama Kimia Indonesia, pp. 99-106. 